\title{
Effect of Uncaria gambir and Uncaria sclerophylla on Pulmonary- Thromboembolism Mice
}

\author{
Aditya Sindu Sakti ${ }^{1}$, Astari Rachma Nityasa ${ }^{2}$, Fadlina Chany Saputri ${ }^{2, *}$
}

Aditya Sindu Sakti ${ }^{1}$, Astari

Rachma Nityasa ${ }^{2}$, Fadlina Chany Saputri ${ }^{2, *}$

'Drug Development Laboratory, Faculty of Pharmacy, Universitas Indonesia, Kampus UI Depok 16424 West Java INDONESIA.

2Department of Pharmacology, Faculty of

Pharmacy, Universitas Indonesia, Kampus UI

Depok, West Java, 16424, INDONESIA.

\section{Correspondence}

\section{Fadlina Chany Saputri}

Department of Pharmacology, Faculty of Pharmacy, Universitas Indonesia, Kampus UI Depok, West Java, 16424, INDONESIA.

E-mail: fadlina.chany@farmasi.ui.ac.id

History

- Submission Date: 28-11-2019;

- Review completed: 04-12-2019;

- Accepted Date: 12-12-2019.

DOI : 10.5530/pj.2020.12.29

Article Available online http://www.phcogj.com/v12/i1

\section{Copyright}

(c) 2020 Phcogj.Com. This is an openaccess article distributed under the terms of the Creative Commons Attribution 4.0 International license.

\begin{abstract}
Background: Previous studies on virtual screening on $\mathrm{P}_{2} \mathrm{Y}_{12}$ receptor of Adenosine Diphosphate (ADP) have showed that Roxburghine $B$, the compound which is found in Uncaria species, can inhibit the receptor function. Objective: In this study, we investigated the effect of Uncaria gambir and Uncaria sclerophylla extract on survival rate and bleeding time as antithrombotic in vivo. Methods: Animal subjects (ddY strain mice) were divided to two different experimental group (survival rate and bleeding time). U. gambir and U. sclerophylla were given to the mice orally in three different dose $(5 \mathrm{mg}, 10 \mathrm{mg}, 20 \mathrm{mg} / 20 \mathrm{~g} \mathrm{BW}$ and $2.5 \mathrm{mg}, 5 \mathrm{mg}, 10 \mathrm{mg} / 20 \mathrm{~g} \mathrm{BW}$, respectively) for seven days. Results: $U$. gambir and $U$. sclerophylla able to prolong bleeding time from test subjects equivalent to ASA as standard. The results show the increasing number of survived animals in the treated group compared to the negative control group. Conclussion: Both of $U$. gambir and $U$. sclerophylla prevent pulmonary thromboembolism on mice subjects represent by the increased of survival rate. Antithrombotic effects that were observed suggested was provide by their antiplatelet activity.

Key words: Antithrombotic, Pulmonary thromboembolism, Bleeding time, Survival rate Uncaria gambir, Uncaria sclerophylla.
\end{abstract}

\section{INTRODUCTION}

The third leading cause of death by cardiovascular disease after myocardial infarction (MI) and cerebrovascular accidents (CVA) is venous thromboembolism (VTE). ${ }^{1}$ VTE is a clinical manifestation from pathophysiology of acute pulmonary embolism (PE) and deep venous thrombosis (DVT). ${ }^{2}$ The thrombi formation in deep veins itself called DVT, when DVT is released, it will travel to the lungs causing a block in blood supply called pulmonary embolism. ${ }^{3}$ If this pathology not treated immediately the mortality will increase about $23-73 \% .{ }^{4}$ Data reported the incidence of VTE annually ranges from 104-183 person cases per year, its similar the rate of stroke cases. Whereas the incidence of PE without DVT ranges from 29-78 cases per 100.000 person for each year. ${ }^{5}$ Of course, this condition will impact on global health problem, reducing the quality of life and mortality of patients.

Pathophysiology and clinical manifestations of PE itself are highly depends on the four main factors, including: the size of the embolism and the degree of vascular occlusion, the patient's condition before, the release of thromboxane and serotonin from platelets that attached to the embolus leading the vasoconstriction. ${ }^{6}$ There are a number of PE treatment strategies such as the administration of low molecular weight heparin (LMWH), that followed or combined with antagonist vitamin $\mathrm{K}$. There are also new strategies with administration of thrombin inhibitors or factor Xa. ${ }^{4}$ Another strategy was the treatment using acetylsalicylic acid (ASA) as thromboprophylaxis agent. Five systematic reviews and five non-randomized primary clinical studies shows that the clinical efficacy of ASA better than LMWH and inhibitors factor Xa. ${ }^{7}$ Low doses oral administration of ASA will provide irreversible inhibition on cyclooxygenase (COX)-1 in order to prevent the thromboxane A2 formation that responsible to platelet aggregation and vasoconstriction. Doses oral administration of AS greater than the dose that used for cardiovascular prophylaxis will also inhibit COX-2 and prostaglandin release. ${ }^{8}$ In contrast with the therapeutic effect, administration of ASA like a "double-edged knife". That is because ASA have a number of adverse effects, such as the risk of bleeding that increases at elderly patients. In addition, a number of diseases such as ulcer peptic, cancer, polypharmacy in geriatric will increase the risk of bleeding incident. ${ }^{9}$ Therefore, the investigation and discovery of new safer thromboprophylaxis agents is important to be encouraged.

In the process of thrombus formation, adenosine diphosphate (ADP) is a major component that responsible for the release of activated platelets. ADP acts as an agonist of two purinergic G-protein coupled receptors, namely: $\mathrm{P} 2 \mathrm{Y}_{1}$ and $\mathrm{P} 2 \mathrm{Y}_{12}$ receptors. Activation of $\mathrm{P} 2 \mathrm{Y}_{1}$ impact on the shape of platelets changes. Synergistically when $\mathrm{P}_{2} \mathrm{Y}_{12}$ is stimulated, the aggregation response occurs will be amplified and stabilized. ${ }^{10}$ In order to obtain animal model for antiplatelet activity test, epinephrine is applied because it ability to induce platelet aggregation mediated by $a-2$ adrenoreceptors. Epinephrine also capable to potentiates aggregation process triggered by a number of platelet agonists such as collagen. YunChoi et al., (2000) reported that the combination of epinephrine and collagen result on platelet shape 
changes without causing an aggregation process. ${ }^{11}$ That fact makes the collagen-ephineprin (CE) combination promising to induce animal model for determination antiplatelet activity

Uncaria genus rich in polyphenol compounds which have beneficial effects on cardiovascular. Besides polyphenol compounds, alkaloid compounds are also contained in the uncaria genus. ${ }^{12,13}$ As reported in previous study, U. gambir and U. sclerophylla contain a number of alkaloids which have hypotensive activity. Moreover, virtual screening on $\mathrm{ADP}$ receptor $\left(\mathrm{P}_{2} \mathrm{Y}_{12}\right)$, revealed that the Roxburghine $\mathrm{B}$ as one of the alkaloids contained in the uncaria genus can inhibit the receptor function. ${ }^{12,14}$ In this study, the bleeding time and survival rate were performed on a mice model to revealed the pulmonarythromboembolism effects of U. gambir and U. sclerophylla.

\section{MATERIALS AND METHODS}

\section{Materials}

Uncaria gambir and Uncaria sclerophylla dried leaf was obtanied from Padang, West Sumatra Indonesia. Both of samples were authenticated by Herbarium University of Andalas. Epinephrine was obtained from Sigma-Aldrich (Nucleos, Singapore) and carboxymethylcellulose (CMC) was from Brataco (Jakarta, Indonesia). Acetylsalicylic acid, collagen, and other chemical reagents were purchased from SigmaAldrich (Tokyo, Japan).

\section{Preparation of extract}

Ethanolic extracts were obtained by extracting dried leaf samples using $70 \%$ ethanol $(\mathrm{v} / \mathrm{v})$, the extraction process performed by maceration method for 72 hours at room temperature. ${ }^{15}$ Liquid extract obtained was then evaporated using a rotary evaporator, until concentrated crude extract yielded. The crude extract was kept at $4^{\circ} \mathrm{C}$ until use. The characteristics of $U$. gambir Roxb. and U. sclerophylla Roxb. leaf have been done and reported in our previous study including phytochemical screening, thin layer chromatography profile and total phenolic content. $^{12}$

\section{Animal experimental design}

The Ethics Committee of Faculty of Medicine, Universitas Indonesia (No. 232/UN2.F1/ETIK/2017) was approved this study. The ddY strain of mice (Mus musculus) weights ranging from 20 - $30 \mathrm{~g}$ were obtained from Faculty of Veterinary, Bogor Agriculture Institute. The acclimatization was carried out for 2 weeks before the experiment, all of mice had free access to a commercial mice pellet and drinking water. The animals were placed in a well-ventilated cage with a constant physical ambient temperature $\left(25 \pm 5^{\circ} \mathrm{C}\right)$ and with 12 hours light-dark periods. The animals were weighed every day and observed for the activity. Only healthy animals were included in this study.

This study was performed to evaluate antithrombotic effect experimently by bleeding time assay and pulmonary thromboembolism in vivo. A total of 30 mice randomly divided into five groups for tail bleeding assay.

Group I: normal control group.

Group II: mice treated with $0.208 \mathrm{mg} / 20 \mathrm{~g}$ BW of ASA, orally for $7 \mathrm{~d}$.

Group III: mice treated with the plant extract (U. gambir: $5 \mathrm{mg} / 20 \mathrm{~g}$ BW; U. sclerophylla: $2.5 \mathrm{mg} / 20 \mathrm{~g} \mathrm{BW}$, orally for $7 \mathrm{~d}$ ).

Group IV: mice treated with the plant extract (U. gambir: $10 \mathrm{mg} / 20 \mathrm{~g}$ BW; U. sclerophylla: $5 \mathrm{mg} / 20 \mathrm{~g} \mathrm{BW}$, orally for $7 \mathrm{~d}$ ).

Group V: mice treated with the plant extract (U. gambir: $20 \mathrm{mg} / 20 \mathrm{~g}$ BW; U. sclerophylla: $10 \mathrm{mg} / 20 \mathrm{~g} \mathrm{BW}$, orally for $7 \mathrm{~d}$ ).
Another total of 36 mice randomly divided into six groups for survival rate assay by pulmonary thromboembolism model.

Group I: normal control group.

Group II: CE control group (received $700 \mu \mathrm{g} /$ mouse of collagen- $42 \mu \mathrm{g} /$ mouse of epinephrine, iv. on $8^{\text {th }}$ day).

Group III: mice treated with $0.208 \mathrm{mg} / 20 \mathrm{~g}$ BW of ASA, orally for $7 \mathrm{~d}$, and received $700 \mu \mathrm{g} /$ mouse of collagen- $42 \mu \mathrm{g} /$ mouse of epinephrine, iv. on $8^{\text {th }}$ day)

Group IV: mice treated with the plant extract (U. gambir: $5 \mathrm{mg} / 20 \mathrm{~g}$ BW; U. sclerophylla: $2.5 \mathrm{mg} / 20 \mathrm{~g} \mathrm{BW}$, orally for $7 \mathrm{~d}$, and received $700 \mu \mathrm{g} /$ mouse of collagen- $42 \mu \mathrm{g} /$ mouse of epinephrine, iv. on $8^{\text {th }}$ day).

Group V: mice treated with the plant extract (U. gambir: $10 \mathrm{mg} / 20 \mathrm{~g}$ BW; U. sclerophylla: $5 \mathrm{mg} / 20 \mathrm{~g} \mathrm{BW}$, orally for $7 \mathrm{~d}$, and received $700 \mu \mathrm{g} /$ mouse of collagen- $42 \mu \mathrm{g} /$ mouse of epinephrine, iv. on $8^{\text {th }}$ day).

Group VI: mice treated with the plant extract (U. gambir: $20 \mathrm{mg} / 20 \mathrm{~g}$ BW; U. sclerophylla: $10 \mathrm{mg} / 20 \mathrm{~g} \mathrm{BW}$, orally for $7 \mathrm{~d}$, and received $700 \mu \mathrm{g} /$ mouse of collagen- $42 \mu \mathrm{g} /$ mouse of epinephrine, iv. on $8^{\text {th }}$ day).

\section{Experimental procedure}

An in vivo assay similar with the previous study ${ }^{16}$ was performed to revealed the effect of both extracts on bleeding time and survival rate. Each of the crude extract with three doses were suspended in $0.5 \%$ CMC-Na to obtain the suspension of plant extract. ASA dissolved in water was then used as a positive control. The suspensions of extract and ASA were administered to treated mice orally for $7 \mathrm{~d}$. Both normal control groups in tail bleeding and survival rate assay were given $0.5 \%$ CMC-Na orally for $7 \mathrm{~d}$.

\section{Tail bleeding assay}

Determination of bleeding time performed by tail bleeding test method. All animal test subjects administrated $10 \mathrm{mg} / \mathrm{kg}$ xylazine and $100 \mathrm{mg} / \mathrm{kg}$ ketamine as an anesthetic, intermittently 5 hours from the last administration of the plant extract or ASA or $0.5 \% \mathrm{CMC}-\mathrm{Na} .{ }^{17}$ The animals were placed in a prone position and the tail dangles down. The tail was cut $10 \mathrm{~mm}$ along lateral vein, then immediately immersed in $50 \mathrm{~mL}$ falcon tube containing normal saline pre-warmed to $37^{\circ} \mathrm{C}$. Observation of bleeding time was performed within $20 \mathrm{~min}$. Rebleeding was monitored even though the bleeding stopped before 20 min. The sum of bleeding time during 20 min period was used for on/ off bleeding cycles. The experiment will be stopped at the end of $20 \mathrm{~min}$ to prevent the death of animals. ${ }^{18}$

\section{Pulmonary thromboembolism model}

An established method from Saputri et al. performed to provide a pulmonary thromboembolism (PE) model. ${ }^{16}$ After 24 hours from the last administration of the plant extract or ASA or $0.5 \% \mathrm{CMC}-\mathrm{Na}$, the mixture solution of collagen and epinephrine (CE) was injected through the tail vein to induce PE. While the normal group was given an injection of normal saline. The lethal and paralysis effects are observed for 15 minutes after induction. The survival rate (\%) was calculated based on the following formula:

$$
\text { Survival rate }(\%)=\left(1-\frac{\text { amount of dead animals }}{\text { amount of animals in the group }}\right)
$$

\section{Stastical analysis}

Result of determination bleeding time assay are presented as mean \pm SD (Standard Deviation) of five data. Homogeneity of data was determined with Levene test, and the data normality was analyzed with the Shapiro-Wilk test. The differences in mean (Table 1.) was analyzed with ANOVA test followed by Tukey and LSD post hoc analysis using SPSS v.22, values of $p<0.05$ were considered to be statistically significant. 


\section{RESULTS}

This study revealed both of $U$. gambir and U. sclerophylla were proven able to prolong bleeding time from test subjects equivalent to ASA as standard. The bleeding time prolongation occurs, was in line with increasing of dose (Figures 1 and 2). Whereas, can observed at Table 1. dose 3 shows the longest bleeding time prolongation. All doses tested compared with control group were significantly different $(p<0.05)$. Pulmonary thromboembolism induction caused $60 \%$ of deaths from each group administrated with $\mathrm{CE}$ injection alone. In accordance with the bleeding time assay performed, administration of $U$. gambir and $U$. sclerophylla capable to increase the survival rate. The highest survival rate for $U$. gambir was observed at dose 3, that shows $80 \%$ of survival rate (Table 2). It means that $U$. gambir was able to increase survival rate 2 times compared to group that administrated $\mathrm{CE}$ alone. $U$. sclerophylla provide the highest survival rate at dose 2 , however at the higher dose (dose 3 ) there was observed decreases in survival rate. This phenomenon suggested because at the dose 3 bleeding event or toxic effect was occurs, further investigation needed to clarify this phenomenon.

\section{DISCUSSION}

U. gambir and $U$. sclerophylla contain a number of phytochemical compounds such as flavonoids, polyphenols and alkaloids. ${ }^{12,14}$ The major phenolic content from Uncaria species is catechins, which are commonly known for their properties as antioxidant. ${ }^{19}$ Catechin that can be found more than $70 \%$ in uncaria extracts, also reported have several antithormbotic effects due its antiplatelet activity. ${ }^{20,21}$ Besides polyphenol, uncaria species also reported to contain a number of

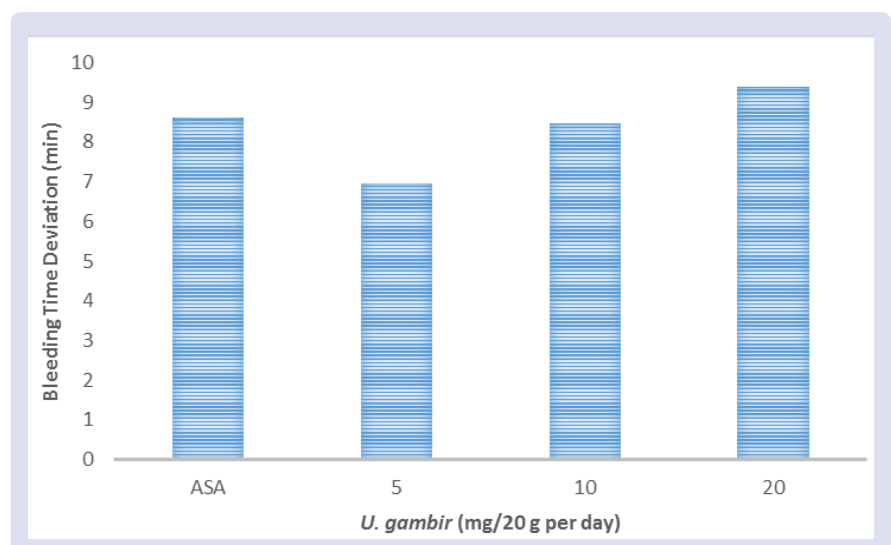

Figure 1: Dose-dependent reduction on bleeding time parameter between U. gambir and control. ASA: acetylsalicylic acid.

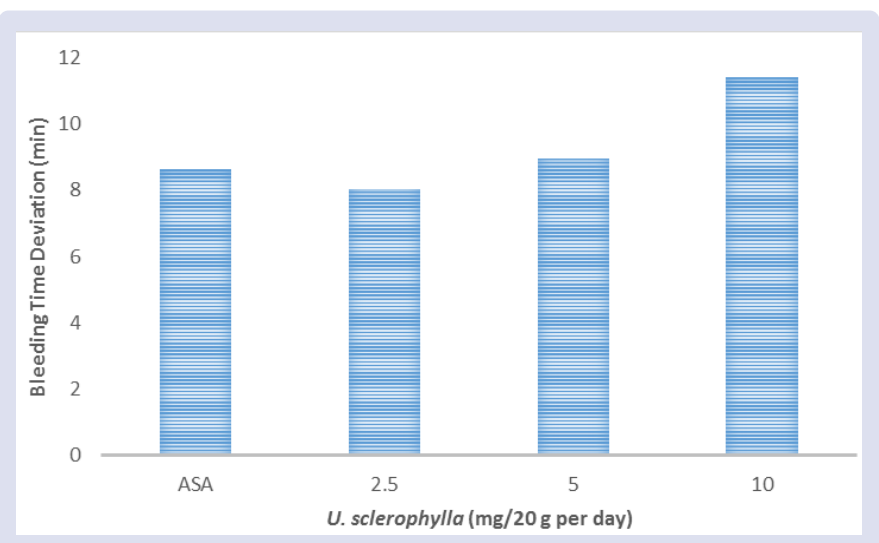

Figure 2: Dose-dependent reduction on bleeding time parameter between U. sclerophylla and control. ASA: acetylsalicylic acid.
Table 1: Mean value of bleeding time.

\begin{tabular}{ccc}
\hline \multirow{2}{*}{ Treatment } & \multicolumn{2}{c}{ Bleeding Time (Mean \pm SD) } \\
\cline { 2 - 3 } & U. gambir extract & U. sclerophylla extract \\
\hline Control & $5.39 \pm 2.21$ & $5.39 \pm 2.21$ \\
ASA & $14.02 \pm 4.20^{*}$ & $14.02 \pm 4.20^{\star}$ \\
Dose 1 & $12.34 \pm 1.24^{*}$ & $13.42 \pm 3.14^{*}$ \\
Dose 2 & $13.85 \pm 3.50^{*}$ & $14.34 \pm 1.07^{\star}$ \\
Dose 3 & $14.78 \pm 3.59^{*}$ & $16.79 \pm 3.39^{*}$ \\
\hline
\end{tabular}

Note: Control (0.5\% CMC vol: $0.3 \mathrm{ml} / 20 \mathrm{~g} \mathrm{BW})$, ASA (0.208 mg/20g BW), U. gambir Dose 1 (5 mg/20 g BW), U. gambir Dose 2 (10 mg/20 g BW), U. gambir Dose 3 (20 mg/20 g BW), U. sclerophylla Dose 1 (2.5 mg/20 g BW), U. sclerophylla Dose 2 ( $5 \mathrm{mg} / 20 \mathrm{~g} \mathrm{BW}), U$. sclerophylla Dose $3(10 \mathrm{mg} / 20 \mathrm{~g} \mathrm{BW})$. * shows $\mathrm{P}<0.05$ as compared to the control group. ASA: acetylsalicylic acid; SD: standard deviation; BW: Body Weight.

Table 2: Survival rate analysis.

\begin{tabular}{ccc}
\hline \multirow{2}{*}{ Treatment } & \multicolumn{2}{c}{ Survival Rate (\%) } \\
\cline { 2 - 3 } & U. gambir extract & U. sclerophylla extract \\
\hline Control & - & - \\
CE & 40 & 40 \\
CE + ASA & 60 & 60 \\
CE + Dose 1 & 60 & 80 \\
CE + Dose 2 & 60 & 83.33 \\
CE + Dose 3 & 80 & 20 \\
\hline
\end{tabular}

Note: Control (0.5\% CMC vol: $0.3 \mathrm{ml} / 20 \mathrm{~g} \mathrm{BW}), \mathrm{CE}(0.5 \% \mathrm{CMC}$ vol: $0.3 \mathrm{ml} / 20$ $\mathrm{g} \mathrm{BW})$, ASA (0.208 mg/20g BW), U. gambir Dose 1 (5 mg/20 g BW), U. gambir Dose 2 (10 mg/20 g BW), U. gambir Dose 3 (20 mg/20 g BW), U. sclerophylla Dose 1 (2.5 mg/20 g BW), U. sclerophylla Dose 2 (5 mg/20 g BW), U. sclerophylla Dose 3 (10 mg/20 g BW). CE: collagen-epinephrine; ASA: acetylsalicylic acid; BW: Body Weight.

alkaloid compounds. Various studies reported that indole alkaloids from uncaria species are responsible for vasodilation effect. Furthermore, previous in silico screening revealed that roxburghine $\mathrm{B}$ which is an indole alkaloid from uncaria, has an inhibitory activity against $\mathrm{P} 2 \mathrm{Y}_{12}$ receptor. ${ }^{14}$ This study confirmed our previous in silico findings, in vivo data (Tables 1 and 2 ) show that $U$. gambir and $U$. sclerophylla has antithrombotic effects.

In the mechanism of platelet aggregation, presence of collagen was required for adhesion of platelet also to completes platelet activation itself. Collagen plays an important role, indirectly in regulating formation of thrombin process. Phosphatidylserine as negatively charged phospholipids for the example, it will only form coagulation catalytic site and form a thrombin after interact with collagen. ${ }^{22}$ Ephineprin is a sympathomimetic catecholamine that works on both of $\alpha$ - and $B$-adrenergic receptors mediated by a $G$ protein-linked second messenger system. At the small amount, ephineprin has higher affinity for $B$-adrenergic receptors, whereas at high doses it provides selective activity to $\alpha$-adrenergic receptors. ${ }^{23}$ Related to antithrombotic effect, ephineprin can increases platelet deposition by $55-85 \%$. Mustonen et al. reported that platelet aggregation mediated by ephineprin was related to phosphorylation of p38MAPK and cytosolic phospholipase A2 (cPLA2) activity, which responsible to arachidonic acid (AA) production from platelet membrane cell. ${ }^{24}$

That description above underlies the application of collagenephineprin (CE) to induce pulmonary thromboembolism (PE) on animal model. Intravenous $\mathrm{CE}$ injection capable to induce platelet activation subsequently implicated lethal incident on animal model immediately. ${ }^{25}$ Moveover, Konstantinides et al. also reported that histological and histochemical examination of CE-induced animal model show the formation of fibrin and fibrinogen rich thormbi. ${ }^{26}$ We have successfully determined antithrombotic effect from various natural product using this CE-induced mice model at the previous 
studies. ${ }^{27-30}$ There are three classes of antithrombotic agents, including: agents that inhibit aggregation of platelet, inhibit fibrin strands formation (known as anticoagulant), and agent that dissolve exiting clots (known as fibrinolytic). Both of antiplatelet and anticoagulant work through preventing thrombogenesis, but not affect the clots that already formed..$^{31}$ Administration of both of extracts intervention for 7 days then subsequently $\mathrm{CE}$ administrated was reveal whether the intervention able to prevent the clots formation or not. The results show that $U$. gambir and U. sclerophylla able to prevent the clots formation and prolong the bleeding time. This result suggested due to antiplatelet activity of $U$. gambir and $U$. sclerophylla through $\mathrm{P} 2 \mathrm{Y}_{12}$ inhibition as reported on in virtual screening before.

\section{CONCLUSION}

Uncaria gambir and Uncaria sclerophylla able to prolong bleeding time and prevent pulmonary thromboembolism represent by the increased of survival rate compared to control. Antithrombotic effects that were observed suggested was provide by antiplatelet activity from Uncaria gambir and Uncaria sclerophylla.

\section{ABBREVIATIONS}

VTE: Venous thromboembolism; MI: Myocardial infarction; CVA: Cerebrovascular accidents; PE: Pulmonary embolism; LMWH: Low molecular weight heparin; ASA: Acetylsalicylic acid; COX: Cyclooxygenase; ADP: Adenosine diphosphate; CE: Collagenephineprin; cPLA2: Cytosolic phospholipase. AA: Arachidonic acid (AA).

\section{ACKNOWLEDGMENT}

The authors would like to give gratitudes to Universitas Indonesia and Ministry of Research and Higher Education for supporting this research with the grant Penelitian Dasar Unggulan Perguruan Tinggi (PDUPT) No. 1472/UN2.R3.1/HKP.05.00/2019.

\section{CONFLICTS OF INTEREST}

The authors declare there is no conflict of interest.

\section{REFERENCES}

1. Swaroop M, Tarbox A. Pulmonary embolism. International Journal of Critical IIIness and Injury Science. 2013;3(1):69.

2. Phillippe H. Overview of Venous Thromboembolism. American Journal of Managed Care. 2017;23:S376-82.

3. Tritschler T, Kraaijpoel N, Le Gal G, Wells P. Venous Thromboembolism. JAMA. 2018;320(15):1583

4. Blondon M, Bounameaux H, Righini M. Treatment strategies for acute pulmonary embolism. Expert Opinion on Pharmacotherapy. 2009;10(7):1159-71.

5. Heit J. Epidemiology of venous thromboembolism. Nature Reviews Cardiology. 2015;12(8):464-74

6. Kostadima E, Zakynthinos E. Pulmonary Embolism: Pathophysiology, Diagnosis, Treatment. Hellenic Journal of Cardiology. 2007;(48):94-107.

7. Poitras V, Adcock L. Acetylsalicylic Acid for Venous Thromboembolism Prophylaxis: Comparative Clinical Effectiveness and Guidelines [Internet]. Ottawa (ON): Canadian Agency for Drugs and Technologies in Health; 2017 Nov 14. Available from: https://www.ncbi.nlm.nih.gov/books/NBK526374.

8. Nagelschmitz J, Blunck M, Kraetzschmar J, Ludwig M, Wensing G, Hohlfeld. Pharmacokinetics and pharmacodynamics of acetylsalicylic acid after intravenous and oral administration to healthy volunteers. Clinical Pharmacology: Advances and Applications. 2014;(6):51.
9. Sirois C, Couture J, Grégoire J. Acetylsalicylic acid for primary prevention of cardiovascular diseases in older patients with diabetes: do the benefits overcome the risks? Therapeutic Advances in Drug Safety. 2012;3(5):213-26.

10. Frelinger A, Michelson A, Gremmel T. Platelet Physiology. Seminars in Thrombosis and Hemostasis. 2016;42(03):191-204.

11. Yun-Choi H, Park K, Pyo M. Epinephrine induced platelet aggregation in rat platelet-rich plasma. Thrombosis Research. 2000;100(6):511-18.

12. Sakti A, Saputri F, Munim A. Microscopic Characters, phytochemical screening focus on alkaloid and total phenolic content of Uncaria gambir Roxb. and Uncaria sclerophylla Roxb. Leaves. Pharmacognosy Journal. 2019;11(1):119-23.

13. Navarro Hoyos M, Sánchez-Patán F, Murillo Masis R, Martín-Álvarez P, Zamora Ramirez W, Monagas $M$ et al. Phenolic Assesment of Uncaria tomentosa L. (Cat's Claw): Leaves, Stem, Bark and Wood Extracts. Molecules. 2015;20(12):22703-17.

14. Sapurti F, Arsyad M, Syahdi R, Yanuar A. Discovery of P2Y12 antagonists through virtual screening of Indonesian herbal database [Draft Manuscript]. Med Chem Comm. 2017.

15. Li S, Dong $X$, Shan $Y$, Liang $Z$, Xun L, Yuan J. Non-alkaloid components from Uncaria sinensis (Oliv.) Havil. and their chemotaxonomic significance. Journal of Medicinal Plants Research. 2011;5(19):4962-67.

16. Saputri F, Nabila N, Mun'im A. Combination of Ginger and Sappan Wood Extract Effect on In vivo Antithrombotic Activity Test. Journal of Young Pharmacists. 2017;9(1):s46-48.

17. Baumgartner B, Jaki T, Wolfsegger M, Eder B, Schiviz A, Schwarz H, et al. Optimization, refinement and reduction of murine in vivo experiments to assess therapeutic approaches for haemophilia A. Laboratory Animals. 2010;44(3):211-7.

18. Liu Y, Jennings N, Dart A, Du X. Standardizing a simpler, more sensitive and accurate tail bleeding assay in mice. World Journal of Experimental Medicine. 2012;2(2):30-6

19. Anggraini T, Tai A, Yoshino T, Intani T. Antioxidative activity and catechin content of four kinds of Uncaria gambir extracts from West Sumatra, Indonesia. African Journal of Biochemistry Research. 2011;5(1):33-8.

20. Taniguchi S, Kuroda K, Doi K, Inada K, Yoshikado N, Yoneda Y, et al. Evaluation of gambir quality based on quantitative analysis of polyphenolic constituents. Yakugaku Zasshi. 2007;127(8):1291-300.

21. Kang W, Chung K, Chung J, Lee J, Park J, Zhang Y, et al. Antiplatelet Activity of Green Tea Catechins Is Mediated by Inhibition of Cytoplasmic Calcium Increase. Journal of Cardiovascular Pharmacology. 2001;38(6):875-84.

22. Farndale R, Sixma J, Barnes M, De Groot P. The role of collagen in thrombosis and hemostasis. Journal of Thrombosis and Haemostasis. 2004;2(4):561-73.

23. Dalal R, Grujic D. Epinephrine. [Updated 2019 Apr 2]. In: StatPearls [Internet] Treasure Island (FL): StatPearls Publishing; 2019 Jan 01. Available from: https:// www.ncbi.nlm.nih.gov/books/NBK482160.

24. Mustonen P, van Willigen G, Lassila R. Epinephrine-Via Activation of P38Mapk-Abolishes the Effect of Aspirin on Platelet Deposition to Collagen. Thrombosis Research. 2001;104(6):439-49.

25. Miao R, Liu J, Wang J. Overview of mouse pulmonary embolism models. Drug discovery today: Disease models. 2010;7(3-4):77-82.

26. Konstantinides S, Schäfer K, Neels J, Dellas C, Loskutoff D. Inhibition of Endogenous Leptin Protects Mice from Arterial and Venous Thrombosis. Arteriosclerosis, Thrombosis, and Vascular Biology. 2004;24(11):2196-201.

27. Saputri F, Nityasa A. Antithrombotic effect of Trigonella Foenum-Graceum on collagen/epinephrine-induced thromboembolism in mice. International Journal of Applied Pharmaceutics. 2018;10(1):56-8.

28. Saputri F, Avatara C. Antithrombotic Effect of Kaempferia galanga L. and Curcuma xanthorrhiza Roxb. on Collagen-epinephrine induced thromboembolism in Mice. Pharmacognosy Journal. 2018;10(6):1149-53.

29. Saputri F, Avatara C, Rachmawati D. Antithrombotic Activity of Tamarindus indica L. in Mice. International Journal of Applied Pharmaceutics. 2018;10(1):358.

30. Azmi N, Nityasa A, Saputri F. Antithrombotic Effect of Mucuna pruriens L. and Coriandrum sativum. Pharmacognosy Journal. 2019;11(2):413-7.

31. Becker D. Antithrombotic Drugs: Pharmacology and Implications for Dental Practice. Anesthesia Progress. 2013;60(2):72-80. 


\section{GRAPHICAL ABSTRACT}

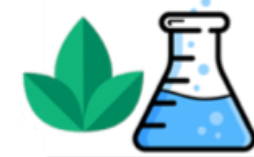

Ethanolic extraction of Uncaria gambir and Uncaria sclerophylla

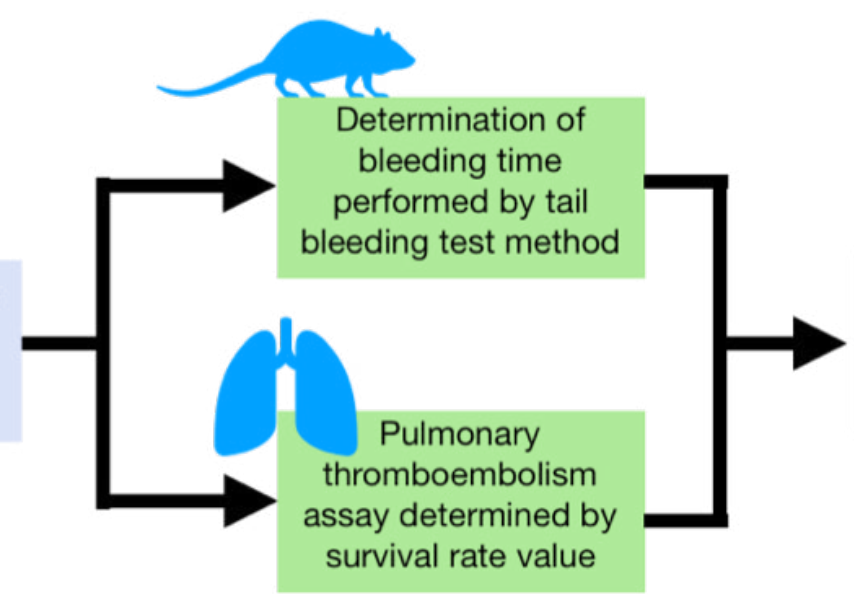

Analysis of Antithrombotic effects

\section{SUMMARY}

The present study investigated the effect of Uncaria gambir and Uncaria sclerophylla extract as antithrombotic by bleeding time assay and pulmonary thromboembolism in vivo. Both of extracts able to prolong bleeding time equivalent to ASA as a positive control. The results also showed the increasing number of survived animals in the treated group compared to the negative control group. Both of U. gambir and U. sclerophylla prevent pulmonary thromboembolism on mice subjects represent by the increased of survival rate. Antithrombotic effects that were observed suggested was provide by their antiplatelet activity.

\section{ABOUT AUTHORS}

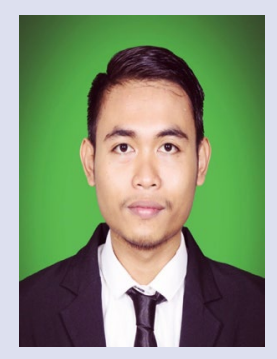

\section{Aditya Sindu Sakti}

Master Student at Herbal Medicine, Faculty of Pharmacy, Universitas Indonesia. His focus research on natural products extraction, green solvent extraction, phytochemical analysis, and dipeptidyl peptidase 4 inhibitory activity from natural product.

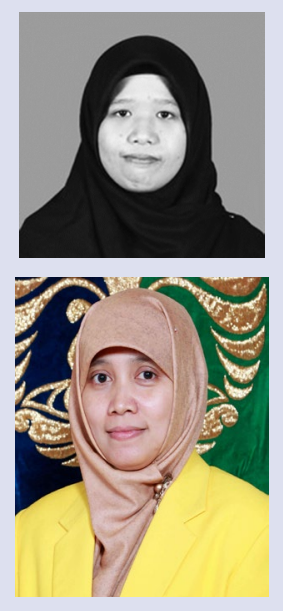

\section{Astari Rachma Nityasa}

Bachelor Student at Faculty of Pharmacy, Universitas Indonesia. Her focus research on in vivo anti-platelet and thromboembolism analysis from natural product.

Cite this article: Sakti AS, Nityasa AR, Saputri FC. Effect of Uncaria gambirand Uncaria sclerophylla on Pulmonary-Thromboembolism Mice. Pharmacog J. 2020;12(1):192-6. 